\title{
The Implementation of Authentic Assessment in Course Syllabus Incorporating the Pragmatic Acquisition
}

\author{
${ }^{1}$ Elli Setiyo Wahyuni*, ${ }^{2}$ Deasy Arieffiani \\ Universitas Hang Tuah Surabaya \\ *Corresponding Author \\ Email: elli.setiyo@ hangtuah.ac.id
}

\begin{abstract}
The fact that students have lack of reading comprehension as the result of ineffective implementation in course syllabus. The study aims at implementing authentic assessment in extensive reading. The objective of activities in authentic assessment is to enhance the students' pragmatic acquisition in understanding political news text. Qualitative method design is used by conducting classroom action research. The finding indicates that the pedagogy implementation provides various tasks in improving the students' pragmatic acquisition. The result reveals that reading strategy can be reinforced through listening, writing, and speaking to have an understanding in a context. Forty-five students in extensive reading class answer open-ended questionnaire and the result shows that pragmatic acquisition is an effective strategy to comprehend the reading text. The integration of authentic assessment and the acquisition of semantic meaning are suggested to be investigated in future research.
\end{abstract}

Keywords: authentic assessment, course syllabus, extensive reading, pragmatic acquisition

\section{INTRODUCTION}

The difficulties in acquiring understanding of reading text have been investigated by various experts (Stemmer, 2009; Borer, 2018; Hsu, 1995). In fact, students are unable to understand texts and interpret them because they are lack of mastery in both vocabulary and English skills (Budiharso, 2014). The most significant factor is inappropriate strategy that has been used by the learners (Albiladi, 2018). In line with this, interpreting every word in the passage using dictionary is one of the incorrect steps (Nurman, 1992). Therefore, pragmatic acquisition has important role to understand the reading text.

Pragmatics is the users' language viewpoint, specifically the interpretation that they decide (Taguchi, 2015). On the other hand, the mastery of English as a foreign language requires linguistic, social, and educational contexts (Cushing, 2017; Hedge, 2003). In line with this, pragmatic skill also has crucial role for English acquisition (Ren \& Han, 2016). Therefore, comprehending the intended meaning is important even though the context is very complex for the students (Taguchi, 2011). These aspects should be used at all level of ability (Siegel et al., 2019). There are several steps to make appropriate understanding of language (Amaya, 2008). Therefore, it is proposed to integrate between assessment and the 
course syllabus in extensive reading with the learning outcome of being able to comprehend the meaning in a text.

Quality, quantity, relevance, and manner are the stages in pragmatic (Han \& Goleman, daniel; Boyatzis, Richard; Mckee, 2019). Quality and quantity relate with the evidences provided in making judgment, whereas, relevance is a real-world situation. Furthermore, manner refers to brief information. In this study, the students are taught to comprehend the text by following the pragmatic concept (Siddiqui, 2018). Political news is the extensive reading material which is relevant to the events, social and digital era (Kareva, 2013; Dykstra, 2019; Takkaç Tulgar, 2016). In line with this, authentic assessment provides various activities that promote pragmatic acquisition, such as performance, portfolio, and project assessment (Rus, 2019). In this study, the pragmatic skill in authentic assessment is applied through the presentation, discussion, natural data, and role-playing.

Integrating authentic assessment in extensive reading is appropriate strategy and enhances the understanding of passage (Bosco \& Ferns, 2014). The detailed activities in a syllabus provide the guidelines and evidence of teaching method used, and the learning progress (Saville et al., 2010). Authentic assessment helps students to be involved in learning, improve motivation, higher-order thinking, knowledge, and self-learner (Fook, 2010; Lohr \& Gall, 2005). Thus, the study aims at implementing authentic assessment in a course syllabus for pragmatic acquisition.

Authentic assessment is used in the curriculum in Indonesia (Aliningsih \& Sofwan, 2015). It is applied according to the course syllabus by integrating the conceptual dimensions, namely realism, cognitive skill, and evaluative judgment (Villarroel et al., 2018). Pragmatism is the integration of real-world context (Bosco $\&$ Ferns, 2014; Saye, 2013). Cognitive means the use of knowledge and higherorder thinking skill (Purpose, 1994). Evaluative judgment is the variety of tasks in formative and summative assessments (Panadero \& Romero, 2014). The course syllabus should reflect these conceptual dimensions to propose the design and activity of authentic assessment in extensive reading (Prokhorets et al., 2015). Therefore, this study aims at designing a course syllabus using conceptual dimensions in authentic assessment.

There are previous researches related to pragmatic acquisition in English language teaching. Understanding sentences in a text requires the understanding of coherence in each (Tyler, 1993; Finch, 2000). In order to comprehend the meaning of a passage, the reader can use semantic and pragmatic meanings (Vandepitte, 2007). In a related study, reading ability can be set in the authentic assessment dimension to improve students' performance and attitudes (Surabaya et al., 2019). In line with this, the application of authentic assessment should measure the reading competence (Rukmini \& Saputri, 2017). The conceptual dimensions of authentic assessment support the extensive reading course design by integration learning outcomes, teaching methods, and the assessment (Biggs, 1999). Two perspectives contribute to the research gap in the educational curriculum. The understanding of pragmatic meaning is more difficult than the understanding of semantic meaning. Therefore, different factor in reading comprehension should be used (Behroozizad \& Bakhtiyarzadeh, 2012). The links between curriculum, instruction, and assessment need to be applied to fulfil the learning goal (Blair \& Lacy, 1993). Based on the explanation above, the purpose of the study is to implement authentic assessment in a course syllabus incorporating pragmatic acquisition. 
The scope of the study is the analysis of pragmatic competence in an extensive reading course. The competence is implemented in the course syllabus by giving an authentic assessment. The study investigates the answer to the following research questions: 1) how to implement conceptual dimensions of authentic assessment in the course syllabus? 2) what is the pedagogy implementation of pragmatic acquisition in a course syllabus? 3) what is the students' perception of pragmatics acquisition?

\section{METHOD}

The study uses a qualitative method design to examine the research questions (Hollstein, 2014). This is a classroom action research that uses content analysis from students' papers, portfolios, projects, and performance assessment. The participants are forty-five students in a private university in Indonesia. An openended questionnaire is used to analyse the students' perception of pragmatic acquisition in a course syllabus (Gulikers et al., 2006).

\section{RESULTS AND DISCUSSION}

The analysis provides the following results related to the development of authentic assessment in a course syllabus, the pedagogy implementation, and the students' perception.

\section{The development of authentic assessment in a course syllabus}

Learning objective is to be able to understand the meaning in the reading text related to political news, authentic assessment is given through portfolio, project, and performance assessments. It also provides formative and summative assessments in the form of quizzes, mid-term and final tests for evaluative judgment. Table 1 presents below sets out the conceptual dimensions in a course syllabus proposed by (Villarroel et al., 2018). It integrates between authentic assessment, the concepts, and the ideas. The course syllabus is developed based on realism, cognitive skill, and evaluative judgment.

Table 1. Conceptual dimensions in a course syllabus

\begin{tabular}{|c|c|c|}
\hline $\begin{array}{l}\text { Authentic assessment } \\
\text { dimensions }\end{array}$ & Concepts & Ideas \\
\hline Pragmatism & $\begin{array}{l}\text { Authentic performance } \\
\text { Competencies }\end{array}$ & $\begin{array}{l}\text { Portfolio and project } \\
\text { Pragmatics acquisition } \\
\text { Similar tasks to the } \\
\text { social context Topics } \\
\text { related to systems of } \\
\text { government, national } \\
\text { and international } \\
\text { political parties, Obama } \\
\text { speech, Donald Trump } \\
\text { speech, general election, } \\
\text { negotiation. }\end{array}$ \\
\hline Cognitive skill & $\begin{array}{l}\text { Higher order thinking } \\
\text { Evaluative judgment }\end{array}$ & $\begin{array}{l}\text { Giving opinion, discussion } \\
\text { ment }\end{array}$ \\
\hline
\end{tabular}

Summative assessment Mid-term test and final 
test: student conference/ group presentation

Based on the findings above, this study suggests some ideas in developing a course syllabus. The pragmatism should cover the activities in extensive reading so that the students can interpret the meaning in a context. The pragmatics acquisition is given through the practices in understanding the reading materials in political news. The tasks support higher-order thinking as the topics related to social context. Moreover, students do various examinations through group presentations, role play, and discussion. It means that understanding meaning is not merely a reading activity, it is also demonstrated in speaking, writing, and listening to have deeper comprehension. Table 2 below indicates the result of the course syllabus which is integrated with the conceptual dimensions.

Table 2. The course syllabus

\begin{tabular}{|c|c|}
\hline Descriptions & Detailed outline \\
\hline Subject & Extensive reading \\
\hline Aims & $\begin{array}{l}\text { By the end of this course students are expected to be able to have: } \\
\text { - A good understanding of text messages related to political information } \\
\text { - Understanding meaning in a context } \\
\text { - Ability to interpret sentences using pragmatic skill } \\
\text { - Understanding topic, main idea, and detailed information in the text }\end{array}$ \\
\hline $\begin{array}{l}\text { Course Description } \\
\text { pragmatic acquisition. }\end{array}$ & This course deals with understanding reading text by practicing \\
\hline Organization of Teaching & The topics are sequenced from simple to complicated. \\
\hline And learning activities & Lecturing will be the technique in delivering the reading text \\
\hline
\end{tabular}

\section{Progressive of the course}

Week 1: Introductory of the course syllabus

Topic: systems of government

Activity: reading text, grammar, discussion.

Portfolio assessment: writing opinion related to systems of government

Week 2: Topic: systems of government

Activity: reading text, vocabulary, listening

Performance assessment: saying opinion about pragmatic meaning in the text

Week 3: Topic discussion: national political parties

Activity: reading text, vocabulary.

Portfolio assessment: a discussion related to political parties

Week 4: Topic discussion: international political parties

Activity: reading text, vocabulary, listening

Performance assessment: group presentation related to international political parties

Week 5: Topic discussion: Obama speech

Activity: reading text, vocabulary, listening

Project assessment: role play

Week 6: Formative assessment/ Quiz

Project assessment: Reading text and group presentation

Week 7: Topic discussion: Obama speech 
Activity: reading text, vocabulary.

Portfolio assessment: understanding meaning and pragmatic in speech

Week 8: Summative assessment/ Mid-term test

Project assessment: student conference (group presentation)

Week 9: Topic discussion: Donald Trump speech

Activity: reading text, vocabulary

Performance assessment: understanding meaning and pragmatic in speech

Week 10: Topic discussion: Donald Trump speech

Activity: reading text, grammar, listening

Portfolio assessment: understanding meaning and pragmatic in speech

Week 11: Topic discussion: general election

Activity: reading text, vocabulary, grammar

Performance assessment: discussion

Week 12: Topic discussion: general election

Activity: reading text, vocabulary, grammar

Portfolio assessment: writing and saying opinion

Week 13: Topic discussion: negotiation

Activity: reading text, vocabulary, listening

Performance assessment: discussion and group presentation

Week 14: Formative assessment/ Quiz

Project assessment: group presentation and role play

Week 15: Topic discussion: negotiation

Activity: reading text, vocabulary, listening

Performance assessment: role-play

Week 16: Summative assessment/ Final test

Project assessment: student conference (group presentation)

\section{The pedagogy implementation}

The results show that most of students are able to comprehend the passage in extensive reading because the lecturer provides intermediate level of reading texts. The chosen text is adjusted to the students' ability in identifying the meaning of vocabulary, background knowledge, and knowledge of world.

The finding also indicates pragmatic acquisition embedded in a course syllabus. The use of several topics related to political news can help students to assess the information from many resources, so that it enhances their understanding. For this reason, the topic related to social context is preferable in order to improve the students' competence in understanding text by using pragmatic meaning. In line with this, some practical pragmatic implementation in a course syllabus is suggested to decrease the problems of reading and to improve students' comprehension ability. The study suggests the following pedagogy implication for extensive reading by using pragmatic acquisition.

\section{A. Introductory of the course syllabus}

A clear guideline is needed to guide students to do their assignments. Information such as types of assignments, individual pair work or group work, test materials, and guidelines for conducting their assignments should be provided to students. 


\section{B. The activity in portfolio and discussion}

Language can provide students with texts that include pragmatically-oriented sentences, for example, the lecturer can ask students questions to help them guess and infer the answer, especially in difficult-to-understand paragraphs, or they can paraphrase the same paragraphs by inserting original text from news, newspapers, and other sources. The reading materials can be discussed at each meeting to interpret the meaning based on the context. Students can compare the results of comprehension through an oral presentation and writing opinions.

\section{The activity in reading material}

The lecturer can encourage the students to avoid looking up any unknown word in the passage in a dictionary. Students are given instructions to read the text and try to develop the understanding by having discussion in group, and searching for relevant topic in other media, such as the use of internet or books. The activity of group discussion will trigger the students' understanding.

\section{The activity in performance assessment}

The students can present an understanding of the text in a group presentation or role-play. In this case, the reading activity can be manifested through speaking. This activity can measure the understanding of reading text. Speaking is the learning outcome from reading activity.

\section{E. The activity in project assessment}

The lecturer should emphasize that formative and summative assessments are not multiple-choice tests. The reading materials are given in the form of an essay that students read several passages and answer the questions using their understanding based on the topics of reading text. In this activity, students can be evaluated their pragmatics acquisition by presenting their text understanding in individual or group work.

\section{F. Listening and vocabulary learning}

In this activity, reading materials can be reinforced using listening and vocabulary exercises to improve the students' comprehension. In this case, listening, vocabulary, and grammar exercises are as the reinforcement.

The activities suggested above provide, will enhance the reading ability by understanding the reading text related to political news. Various reinforcements and activities improve understanding, higher-order thinking, and pragmatics acquisition. Classroom activities, such as those mentioned here, will help students become successful in their pragmatic acquisition.

\section{The students' perception of pragmatic acquisition}

This study uses an open-ended questionnaire to gather more in-depth answers from the students (Belli \& Houtkoop-Steenstra, 2001). The aim is to know the impact of pragmatic acquisition in an extensive reading syllabus. 


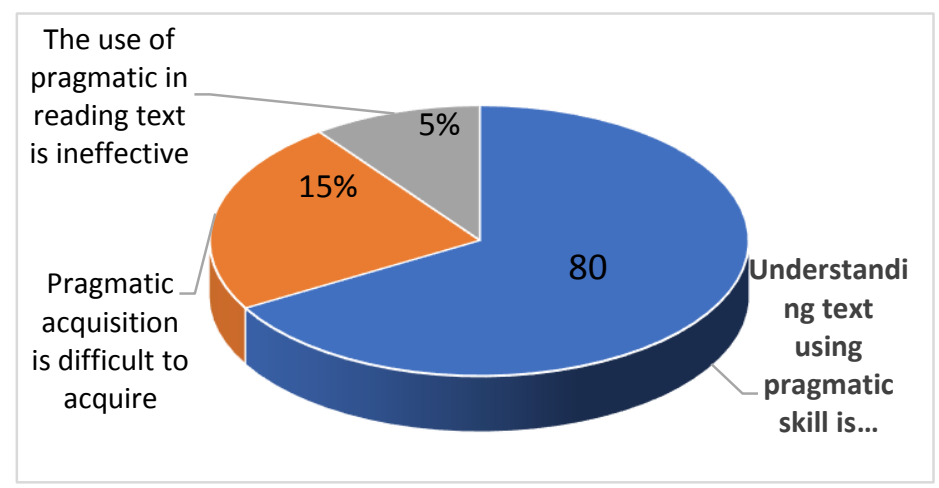

Figure 1. The students' perception of pragmatic acquisition

Figure 1 illustrates the percentage of students' perception of the impact of learning pragmatic to comprehend the reading text. Overall, it can be seen that the most effective learning method is the use of pragmatic acquisition in an extensive reading course. The strategy gives positive impacts to the students in understanding meaning in context and interpreting passages and sentences related to political topics. Furthermore, the application of the course syllabus contributes to language achievement and cognitive skills. In contrast, some students mention that pragmatic acquisition is difficult to acquire and it has a low percentage of $15 \%$. Meanwhile, the ineffective pragmatic in the reading text has the least output (5\%). It can be summarized that most of the students give their opinions about the learning process in extensive reading. The perceptions are in term of the chosen materials which is related to politics and the activity to encourage the students to have various tasks in authentic assessment. To conclude, the implementation of authentic assessment in a course syllabus improves the students' pragmatic acquisition.

\section{CONCLUSION}

It is proven that the use of pragmatic skills enhances understanding and students know how to interpret the text based on the social context. The tasks in authentic assessment, such as portfolio, project, and performance provide the practical pragmatic implementation. In line with this, pragmatics gives practices on interpretation, and the respond to the text meaning in a social context (Taguchi, 2011). The pedagogy suggests several ways in understanding text by not reading and finding the meaning of vocabularies, but pragmatic acquisition can be implemented through speaking, listening, and writing activities. It can be concluded that authentic assessment in a course syllabus contributes to learning achievement and pragmatic acquisition. The study promotes the use of semantic meaning for future research. As (H.Douglas Brown, 2000) suggests two types of meaning, namely semantic and pragmatics. Such an approach serves as a need analysis for future pragmatic instruction.

\section{ACKNOWLEDGEMENTS}

The author thanks to all researchers and lecturers in the Department of Public Administration, Faculty of Political and Social Sciences, Universitas Hang Tuah Surabaya who actively participate in the process of observation and data analysis. 


\section{REFERENCES}

Albiladi, W. S. (2018). Effective English Reading Strategies: English Language Learners' Perceptions. International Journal of English and Education, 7(June 2018), 273-281. https://www.researchgate.net/publication/337862324_Effective_English_Re ading_Strategies_English_Language_Learners'_Perceptions

Aliningsih, F., \& Sofwan, A. (2015). English Teachers' Perceptions and Practices of Authentic Assessment. Language Circle: Journal of Language and Literature, 10(1), 19-27. https://doi.org/10.15294/lc.v10i1.4154

Amaya, L. F. (2008). Teaching Culture: Is It Possible to Avoid Pragmatic Failure? Revista Alicantina de Estudios Ingleses, 21, 11-24. http://citeseerx.ist.psu.edu/viewdoc/download?doi=10.1.1.571.6946\&rep=re p1\&type $=$ pdf

Behroozizad, S., \& Bakhtiyarzadeh, H. (2012). Pragmatic Meaning and EFL Learners' Text-understanding Ability. English Language and Literature Studies, 2(1), 28-34. https://doi.org/10.5539/ells.v2n1p28

Belli, R. F., \& Houtkoop-Steenstra, H. (2001). Interaction and the Standardized Survey Interview: The Living Questionnaire. Contemporary Sociology, 30(6), 657. https://doi.org/10.2307/3089052

Biggs, J. (1999). Teaching for Quality Learning at University. Assessing for learning quality: II. Practice. Teaching for Quality Learning at University, January 2003, 165-203.

Blair, J., \& Lacy, M. G. (1993). from the SAGE Social Science Collections . Rights Reserved . The ANNALS of the American Academy of Political and Social Science, 503(1), 122-136.

Borer, B. (2018). Teaching and Learning Pragmatics and Speech Acts: An Instructional Pragmatics Curriculum Development Project for EFL Learners. https://digitalcommons.hamline.edu/hse_cp/176

Bosco, A. M., \& Ferns, S. (2014). Embedding of authentic assessment in workintegrated learning curriculum. Asia-Pacific Journal of Cooperative Education, 15(4), 281-290.

Cushing, S. T. (2017). Corpus linguistics in language testing research. Language Testing, 34(4), 441-449. https://doi.org/10.1177/0265532217713044

Dykstra, A. (2019). Critical reading of online news commentary headlines: Stylistic and pragmatic aspects. Topics in Linguistics, 20(2), 90-105. https://doi.org/10.2478/topling-2019-0011

Fan, Y.-C. (2010). The Effect of Comprehension Strategy Instruction on EFL Learners' Reading Comprehension. Asian Social Science, 6(8), 19-29. https://doi.org/10.5539/ass.v6n8p19

Finch, G. (2000). Linguistic Terms and Concepts. Linguistic Terms and Concepts. https://doi.org/10.1007/978-1-349-27748-3

Fook. (2010). Authentic Assessment and Pedagogical Strategies in Higher Education. Journal of Social Sciences, 6(2), 153-161. https://doi.org/10.3844/jssp.2010.153.161

Gulikers, J. T. M., Bastiaens, T. J., Kirschner, P. A., \& Kester, L. (2006). Relations Between Student Perceptions of Assessment Authenticity, Study Approaches and Learning Outcome. Studies in Educational Evaluation, 32(4), 381-400. https://doi.org/10.1016/j.stueduc.2006.10.003 
H.Douglas

Brown.

(2000).

[H._Douglas_Brown]_Teaching_by_Principles,_Second_(BookFi.org).pdf.

In Teaching by Principles An Interactive Approach to Language Pedagogy (p. 491).

Han, E. S., \& goleman, daniel; boyatzis, Richard; Mckee, A. (2019). 済無No Title No Title. Journal of Chemical Information and Modeling, 53(9), 1689-1699.

Hedge, T. (2003). The Practice of English Language Teaching. In ELT Journal (Vol. 57, Issue 4, pp. 401-405). https://doi.org/10.1093/elt/57.4.401

Hollstein. (2014). Mixed Methods Soial Networks Research: An Introduction. Mixed Methods Social Networks Research: Design and Applications, 3-34.

Hsu, S. (1995). the Reading Strategies Used By 技職學生英文閱讀策略使用之研 究 許淑真. 2, 159-174.

Kareva, V. (2013). English for Specific Purposes: Public Administration and Political Sciences. Procedia - Social and Behavioral Sciences, 70, 14771481. https://doi.org/10.1016/j.sbspro.2013.01.214

Lohr, L., \& Gall, J. E. (2005). Curriculum, plans, and processes in instructional design: International perspectives. In Educational Technology Research and Development (Vol. 53, Issue 3). https://doi.org/10.1007/bf02504802

Nurman, A. (1992). EXPLORING EFL TEACHERS' STRATEGIES IN TEACHING READING COMPREHENSION By: Nurman Antoni. Issn, 11(2), 39-51. http://jurnal.upi.edu/file/5-Nurman_Antoni.pdf

Panadero, E., \& Romero, M. (2014). To rubric or not to rubric? The effects of selfassessment on self-regulation, performance and self-efficacy. Assessment in Education: Principles, Policy and Practice, 21(2), 133-148. https://doi.org/10.1080/0969594X.2013.877872

Péter. (2002). The Cambridge guide to teaching english to speakers of other languages. R. Carter D. Nunan. ELT Journal, 56(1), 87-89. https://doi.org/10.1093/elt/56.1.87

Prokhorets, E. K., Plekhanova, M. V., \& Scherbinina, N. G. (2015). Instructional Design of Foreign Language Blended Courses. Procedia - Social and Behavioral Sciences, 215(June), 161-169. https://doi.org/10.1016/j.sbspro.2015.11.611

Purpose, E. (1994). Assessing student performance: exploring the purpose and limits of testing. In Choice Reviews Online (Vol. 31, Issue 10). https://doi.org/10.5860/choice.31-5581

Ren, W., \& Han, Z. (2016). The representation of pragmatic knowledge in recent ELT textbooks. ELT Journal, 70(4), 424-434. https://doi.org/10.1093/elt/ccw010

Rukmini, D., \& Saputri, L. A. D. E. (2017). The authentic assessment to measure students' English productive skills based on 2013 Curriculum. Indonesian Journal of Applied Linguistics, 7(2), 263-273. https://doi.org/10.17509/ijal.v7i2.8128

Rus, D. (2019). Assessment Techniques in Teaching English for Specific Purposes to Engineering Students. Procedia Manufacturing, 32, 368-373. https://doi.org/10.1016/j.promfg.2019.02.227

Saville, B. K., Zinn, T. E., Brown, A. R., \& Marchuk, K. A. (2010). Syllabus Detail and Students' Perceptions of Teacher Effectiveness. Teaching of Psychology, 
37(3), 186-189. https://doi.org/10.1080/00986283.2010.488523

Saye, J. (2013). Authentic pedagogy: Its presence in social studies classrooms and relationship to student performance on state-mandated tests. Theory and Research in Social Education, 41(1), 89-132. https://doi.org/10.1080/00933104.2013.756785

Siddiqui, A. (2018). "The principle features of English Pragmatics in applied linguistics." Advances in Language and Literary Studies, 9(2), 77. https://doi.org/10.7575/aiac.alls.v.9n.2p.77

Siegel, J., Broadbridge, J., \& Firth, M. (2019). Saying it "just right": Teaching for pragmatic success in ELT. ELT Journal, 73(1), 31-40. https://doi.org/10.1093/elt/ccy018

Stemmer, B. (2009). Neuropragmatics. The Handbook of Clinical Linguistics, 6178. https://doi.org/10.1002/9781444301007.ch4

Surabaya, U. N., Surabaya, U. N., \& Surabaya, U. N. (2019). Effectiveness of Authentic Assessment: Performances, Attitudes, and Prohibitive Factors. 16(2), 156-175. https://doi.org/10.12973/tused10272a

Taguchi, N. (2011). Teaching pragmatics: Trends and issues. Annual Review of Applied Linguistics, 31(March 2011), 289-310. https://doi.org/10.1017/S0267190511000018

Taguchi, N. (2015). Instructed pragmatics at a glance: Where instructional studies were, are, and should be going. Language Teaching, 48(1), 1-50. https://doi.org/10.1017/S0261444814000263

Takkaç Tulgar, A. (2016). The Role of Pragmatic Competence in Foreign Language Education. Turkish Online Journal of English Language Teaching, 1(1), 1019. https://doi.org/10.32959/tojelt.229304

Tyler, A. (1993). DISCOURSE AND LANGUAGE EDUCATION. Evelyn Hatch. Cambridge: Cambridge University Press, 1992. Pp. xi + 333. \$49.95 cloth, \$16.95 paper. Studies in Second Language Acquisition, 15(3), 387-388. https://doi.org/10.1017/s027226310001216x

Vandepitte, S. (2007). Semantic and Pragmatic Meanings in Translation. Belgian Journal of Linguistics, 21(August), 185-200. https://doi.org/10.1075/bj1.21.13van

Villarroel, V., Bloxham, S., Bruna, D., Bruna, C., \& Herrera-Seda, C. (2018). Authentic assessment: creating a blueprint for course design. Assessment and Evaluation in Higher Education, 43(5), 840-854. https://doi.org/10.1080/02602938.2017.1412396 


\section{APPENDIX}

The result of coding in the open-ended questionnaire.

\begin{tabular}{|c|c|c|c|}
\hline No & Questions & Answers & Category \\
\hline \multirow[t]{3}{*}{1} & \multirow[t]{3}{*}{$\begin{array}{l}\text { Is pragmatic in reading } \\
\text { text beneficial to be used? }\end{array}$} & $\begin{array}{l}\text { The pragmatic acquisition helps } \\
\text { the student to understand the } \\
\text { meaning of a text. }\end{array}$ & $\mathbf{A}$ \\
\hline & & $\begin{array}{l}\text { I prefer another strategy for } \\
\text { comprehension. It is ineffective }\end{array}$ & $\mathbf{B}$ \\
\hline & & $\begin{array}{l}\text { The pragmatic acquisition is } \\
\text { difficult to acquire }\end{array}$ & $\mathbf{C}$ \\
\hline \multirow[t]{2}{*}{2} & \multirow[t]{2}{*}{$\begin{array}{l}\text { Do you easily interpret the } \\
\text { meaning in reading text? }\end{array}$} & $\begin{array}{l}\text { I can interpret well. Pragmatic } \\
\text { acquisition in this learning is } \\
\text { effective }\end{array}$ & $\mathbf{A}$ \\
\hline & & I find it difficult to interpret & $\mathbf{C}$ \\
\hline \multirow[t]{2}{*}{3} & \multirow{2}{*}{$\begin{array}{l}\text { Are the tasks in } \\
\text { portfolio/portfolio/ } \\
\text { performance creative } \\
\text { methods to improve the } \\
\text { understanding of text? }\end{array}$} & $\begin{array}{l}\text { All the tasks in the authentic } \\
\text { assessment improve my } \\
\text { understanding }\end{array}$ & $\mathbf{A}$ \\
\hline & & $\begin{array}{l}\text { All the tasks in the authentic } \\
\text { assessment are creative method } \\
\text { but they are time-consuming } \\
\text { and difficult to understand }\end{array}$ & $\mathbf{C}$ \\
\hline \multirow[t]{2}{*}{4} & \multirow[t]{2}{*}{$\begin{array}{l}\text { What are the benefits of } \\
\text { practicing pragmatic skills } \\
\text { in reading text? }\end{array}$} & $\begin{array}{l}\text { I can cooperate well and share } \\
\text { the meaning of the text }\end{array}$ & $\mathbf{A}$ \\
\hline & & $\begin{array}{l}\text { I can cooperate well but another } \\
\text { media of learning might be } \\
\text { suitable for me }\end{array}$ & B \\
\hline \multirow[t]{2}{*}{5} & \multirow{2}{*}{$\begin{array}{l}\text { Do formative and } \\
\text { summative assessments } \\
\text { measure your ability in } \\
\text { understanding text? }\end{array}$} & $\begin{array}{l}\text { Formative and summative } \\
\text { assessments measure my ability } \\
\text { in understanding text }\end{array}$ & $\mathbf{A}$ \\
\hline & & $\begin{array}{l}\text { Formative and summative } \\
\text { assessments do not measure my } \\
\text { ability in reading. It is not } \\
\text { effective }\end{array}$ & $\mathbf{B}$ \\
\hline \multirow[t]{2}{*}{6} & \multirow{2}{*}{$\begin{array}{l}\text { Are the topics related to } \\
\text { politics relevant to real- } \\
\text { world context? }\end{array}$} & $\begin{array}{l}\text { The topics are relevant to the } \\
\text { real-world context }\end{array}$ & $\mathbf{A}$ \\
\hline & & $\begin{array}{l}\text { The topics are not beneficial to } \\
\text { my language achievement }\end{array}$ & B \\
\hline \multirow[t]{2}{*}{7} & \multirow[t]{2}{*}{$\begin{array}{l}\text { Does pragmatic } \\
\text { acquisition enhance your } \\
\text { reading skill? }\end{array}$} & $\begin{array}{l}\text { Pragmatic is beneficial in } \\
\text { enhancing cognitive skill }\end{array}$ & $\mathbf{A}$ \\
\hline & & $\begin{array}{l}\text { Pragmatic does not enhance my } \\
\text { reading skill. It is difficult to } \\
\text { apply it in understanding text }\end{array}$ & $\mathbf{C}$ \\
\hline
\end{tabular}


The result of coding in percentage.

$A=$ understanding text using a pragmatic skill is beneficial $(80 \%)$

$\mathrm{B}=$ the use of pragmatic in reading text is ineffective $(5 \%)$

$\mathrm{C}=$ pragmatic acquisition is difficult to acquire (15\%) 